Acta Protozool. (2019) 58: 125-139 www.ejournals.eu/Acta-Protozoologica doi:10.4467/16890027AP.19.013.11914 PROTOZOOLOGICA

\title{
Taxonomic Assessment of Three North American Trichodinids by Re- evaluating the Taxon Validity of Trichodina heterodentata Duncan, 1977 (Peritrichia)
}

\author{
Gerhard P. de Jager, Linda Basson \\ Department of Zoology and Entomology, University of the Free State, Bloemfontein, South Africa
}

\begin{abstract}
Trichodina heterodentata was first described from fish breeding farms in the Philippines by Bryan Duncan in 1977 as ectoparasites of imported cichlids, more specifically the southern African Oreochromis mossambicus (Peters, 1852) from the Limpopo River System. This trichodinid has subsequently been described from almost every continent, bar North America. Being a cosmopolitan species, with a preference for cichlid hosts, it has unambiguous morphological features, but with distinct variances between and within populations. After reviewing previous descriptions of North American trichodinids, analysing the morphological data (both generally published information along with the original type material from the Smithsonian Museum, Washington, U.S.A.) and investigating the distribution patterns of the southern African introduced O. mossambicus throughout the North American water systems, three of the four studied trichodinids (T. hypsilepis Wellborn, 1967, T. salmincola Wellborn, 1967 and T. vallata Wellborn, 1967) are proposed to represent the same species as T. heterodentata. According to nomenclature rules T. hypsilepis henceforth represents the valid taxon (synonyms: T. salmincola, T. vallata and $T$. heterodentata). This not only questions the validity of several trichodinid species, but also indicates the probability of an African alien introduction into North America.
\end{abstract}

Keywords: Trichodina hypsilepis, T. heterodentata, Oreochromis mossambicus.

\section{INTRODUCTION}

Members of the family Trichodinidae Raabe, 1959 are all protozoan, ciliophoran mobiline ecto- and endosymbionts, using the tissue of their hosts as a substrate to hover across or to temporarily attach to. Trichodinids are usually associated with freshwater, estuarine or marine teleost fishes, but have also been described from amphibians (Fulton 1923; Lom 1958; Kazubski

\footnotetext{
Address for correspondence: L. Basson, Department of Zoology and Entomology, University of the Free State, PO Box 339, Bloemfontein, 9300, South Africa, E-mail: bassonl@ufs.ac.za
}

1988; Kruger et al. 1991, 1993, 1995; Dias et al. 2009), aquatic and terrestrial invertebrates (Basson and van As 1991, 1992; Kazubski 1991), found in the urinary tract of chondrichthyans (van As and Basson 1996) and recently in the reproductive tracts of waterfowl (Carnaccini et al. 2016). Members of the family Trichodinidae are highly cosmopolitan with more than 300 species described, representing 11 genera (Basson and van As 1989, van As and Basson 1993, Hu 2011), with the genus Trichodina Ehrenberg, 1830, having the largest number of species. According to Lom (1958) representatives within the family Trichodinidae are primarily identified on morphological differences in the reach 
of their adoral spiral and structure of the aboral denticle ring of the adhesive disc.

One of the species from the genus Trichodina with a cosmopolitan distribution and commonly encountered from a variety of freshwater fish hosts is $T$. heterodentata Duncan, 1977 (Pádua et al. 2012, Valladão et al. 2016) showing a distinct preference for cichlids (Basson and van As 2006). Trichodina heterodentata was initially described by Duncan (1977) from the Philippines from three fish species, with the holotype population described from Oreochromis mossambicus (Peters, 1852), a native fish from southern Africa. The Mozambique tilapia is probably one of the most widely distributed aquaculture fishes, to such a degree that it has been declared an invasive species in certain parts of the world (Wilson et al. 2019).

Trichodina heterodentata is credited in having a large range of biometric variation in its denticle structure, hence Duncan's (1977) comments and reason for naming this species. Using the large variation in adhesive disc morphometrics, all T. heterodentata populations described from various hosts were clumped into three overarching groupings in the present study.

Even though trichodinids have been described from the United States of America by Fulton (1923), Mueller (1937), Hirshfield (1949), Uzmann and Stickney (1954) and Wellborn (1967), there have basically been no recent records.

An important contribution was made by Wellborn (1967) when he described eight new and ten known species from freshwater teleost hosts from the South-eastern U.S. Of these new species, T. hypsilepis Wellborn, 1967, T. salmincola Wellborn, 1967, T. vallata Wellborn, 1967 and T. funduli Wellborn, 1967 shared similar denticle morphology and biometrics as those of the cosmopolitan T. heterodentata. Both Wellborn (1967) and Duncan (1977) used the morphological characteristics proposed by Lom (1958) in their descriptions, although not all the new species were described using silver impregnated specimens.

The present paper investigates the validity of four trichodinid species of Wellborn (T. hypsilepis, T. salmincola, $T$. vallata and $T$. funduli), comparing these relatively unknown species with the well-stud- ied $T$. heterodentata by incorporating alpha-taxonomy from historical data and examining museum type material. Comments are also provided on the introduction of $T$. heterodentata from the southern African continent into North America by tracing the distribution history of the cichlid fish O. mossambicus and the validity of certain North American trichodinid species.

\section{MATERIAL AND METHODS}

Photomicrographs used in this study for the re-measurements of biometric data were based on the original museum type material (holo- and paratypes) housed in the Protozoan and Helminth collections of the Smithsonian Institute in Washington, USA. The type material for T. heterodentata was collected by Duncan (1977) from three populations of freshwater teleost hosts (USNM No. 24485, USNM 24486 and USNM No. 24487) in the Philippines. Wellborn's (1967) type material was used for Trichodina hypsilepis (USNM No. $61651 \& 61652)$ and T. funduli $(1357367 \& 1357368)$ from Alabama, T. salmincola (USNM 1357379 \& 1357380) from North Carolina and T. vallata (USNM 1357384) from Georgia. The abovementioned material was collected from various species of freshwater fish hosts (see Wellborn 1967).

The type material for these five species was impregnated with silver nitrate by the original authors using Klein's (1926) method, as recommended by Lom (1958). All these morphometric measurements follow the proposed uniform characteristics system suggested by Lom (1958) and are given in micrometres $(\mu \mathrm{m})$. Minimum and maximum values, followed by the arithmetic mean and standard deviation, are provided where possible. For two characteristics; number of denticles and number of radial pins per denticle, the mode, rather than the arithmetic mean, is provided. Denticle descriptions for all species from the Smithsonian micrographs were done according to the methods proposed by van As and Basson (1989), except for T. funduli, since the type material destained to such a degree that denticle details could not be determined.

\section{RESULTS}

Morphometric measurements of the type material from the Smithsonian of Duncan's (1977) original T. heterodentata populations (Figs 1-3) and Wellborn's original descriptions for T. hypsilepis, T. salmincola, T. vallata and T. funduli (Figs 4-6) are provided in Tables 1 and 2 .

Figs 1-6. Micrographs of representative specimens from the paratype material of Duncan's (1977) Trichodina heterodentata Duncan, 1977 (Figs 1-3) and Wellborn's (1967) (Figs 4-6) collections at the Smithsonian Institute, 1 - Population A from Oreochromis mossambicus (Peters, 1885) hosts, 2 - Population B from Coptodon zillii (Gervais, 1884), 3 - Population C from Trichopodus trichopterus (Pallas, 1770), 4 - Trichodina hypsilepis Wellborn, 1967 from Notropis hypsilepis Suttkus \& Raney, 1955, 5 - T. salmincola Wellborn, 1967 from Oncorhynchus mykiss (Walbaum, 1792) and 6 - T. vallata Wellborn, 1967 from Ictalurus punctatus (Rafinesque, 1818). Scale bars: 50 m. 

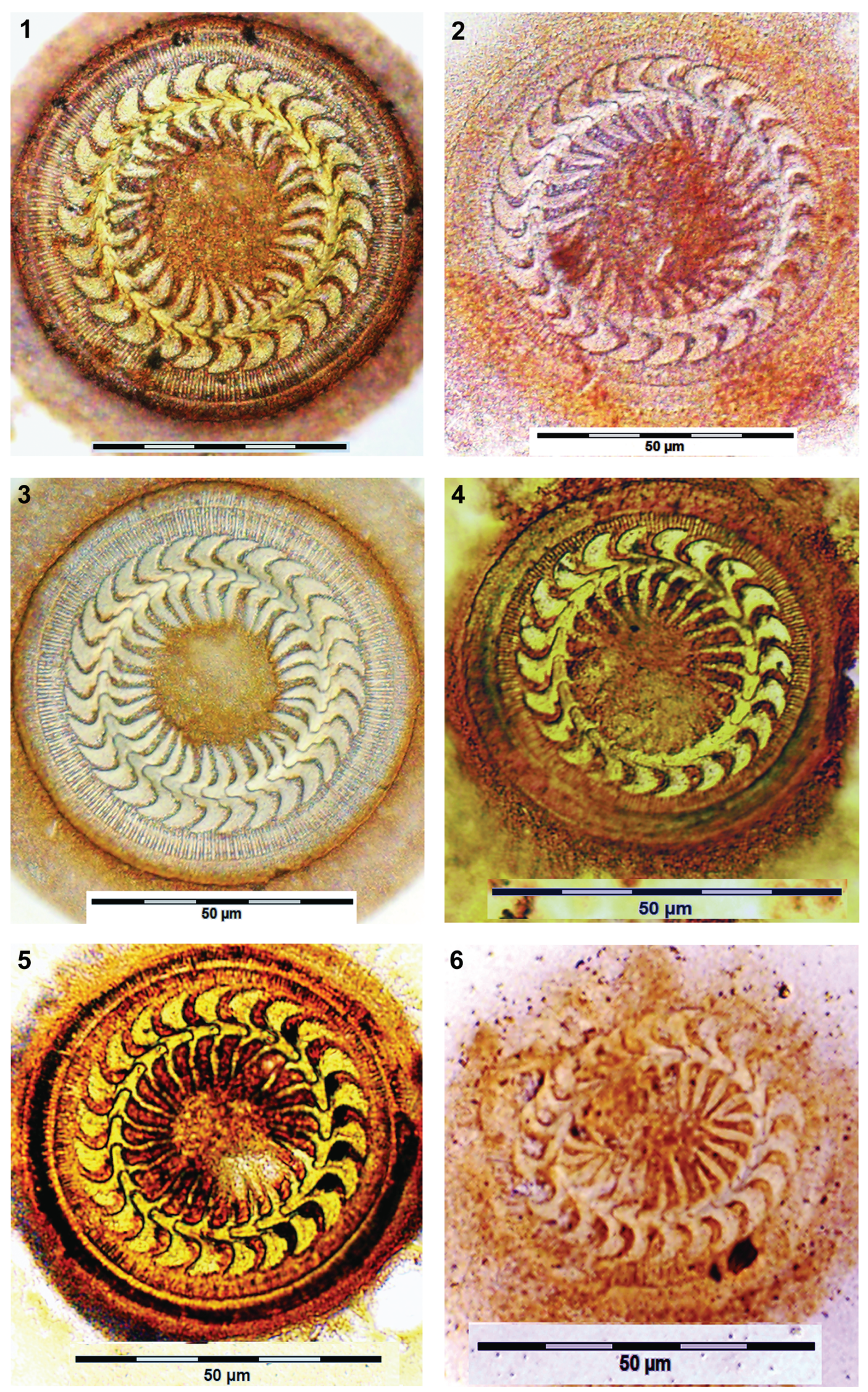


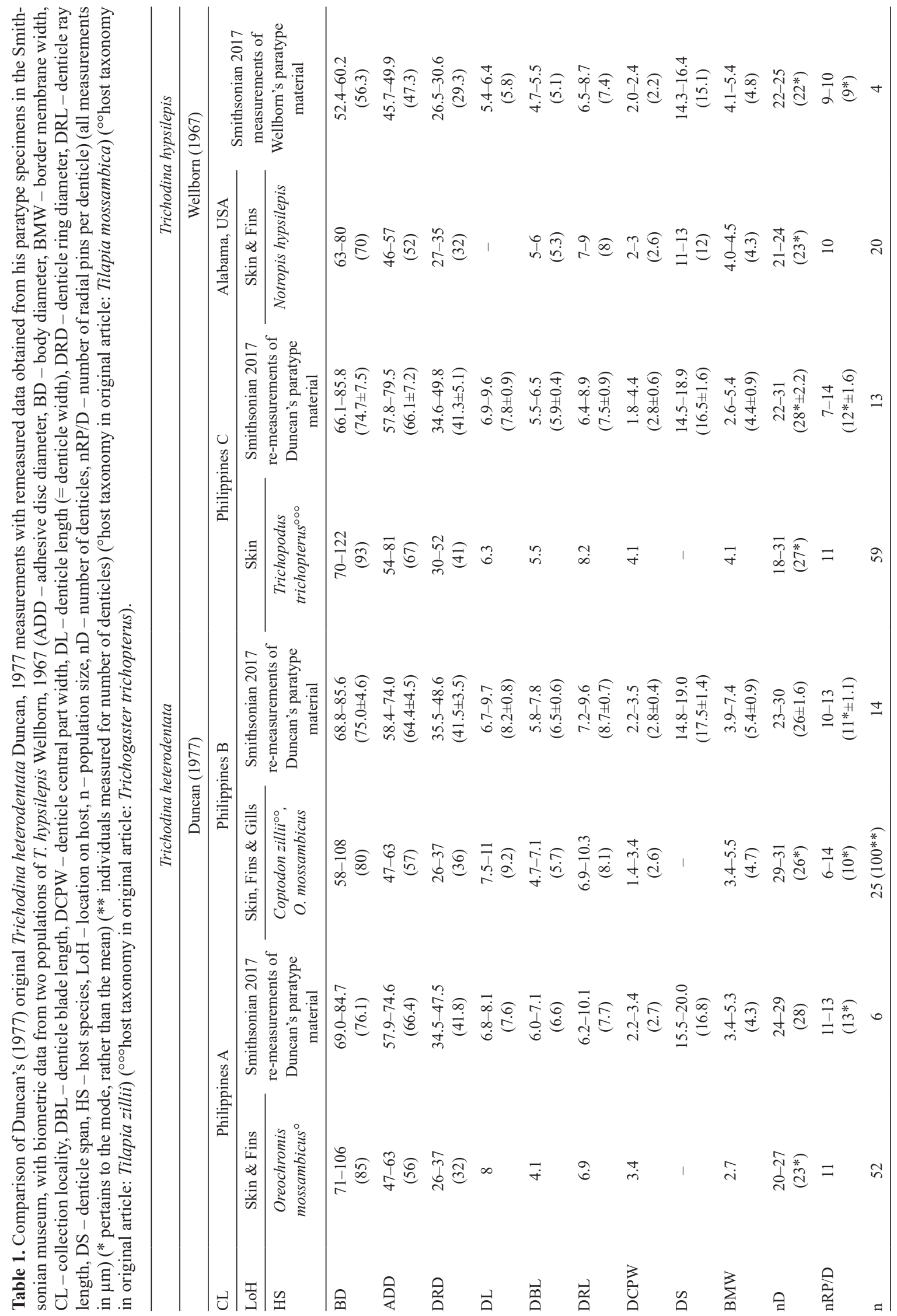




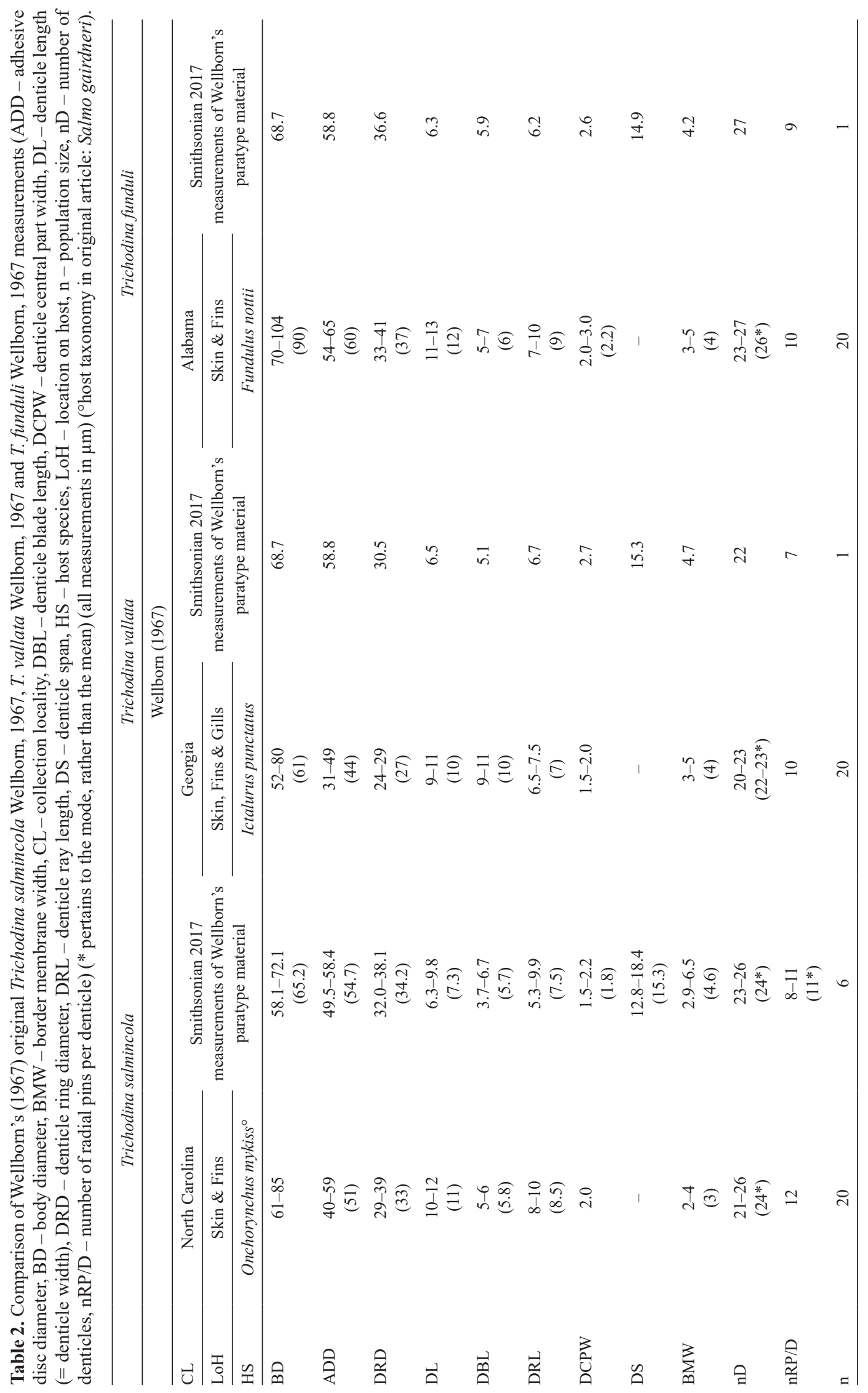


Morphological descriptions from the Smithsonian type material follows:

Trichodina heterodentata Duncan, 1977 (Figs 1-3, 7a-c) (Table 1)

Hosts: Oreochromis mossambicus (Peters, 1852), Mozambique tilapia (population A), Coptodon zillii (Gervais, 1848), redbelly tilapia (population B) and Trichopodus trichopterus (Pallas, 1770) (previously Trichogaster trichopterus), three spot gurami (Population C).

Location on host: Gills, body and fins.

Locality: Populations A, B and C from the Freshwater Aquaculture Centre, Central Luzon State University, Muños, Nueva Ecija, Philippines.

Specimens: Holotype slide USNM No. 24485 (Population A), Paratype slide USNM No. 24486 (Population B) and Paratype slide USNM No. 24487 (Population C) (Smithsonian).

Description: Remeasured type material results and Duncan's (1977) original morphometric data are provided in Table 1.

Population A (Fig. 7a): Blade strongly developed, sickle-shaped, filling most of area between y axes. Distal blade margin mostly smooth, sloping gradually with posterior part of distal margin parallel to border membrane and anterior part at angle to border membrane. Tangent point relatively narrow, situated slightly proximal to distal blade margin. Anterior blade margin mostly smoothly rounded, extending slightly past $y+1$ axis in most cases. Blade apophysis present and prominent. Posterior blade surface shallow V- to L-shaped in majority of denticles, with deepest point on same level as blade apex. No posterior projection present/observed. Slight posterior projection present, fitting into corresponding notch distal to central part of following denticle. Blade connection very strongly developed, thicker or as thick as central part width. Central part robust, with notched proximal and distal edges, broad base narrowing slightly posteriorly, fitting tightly into preceding denticle and extending halfway towards y axes. Central part distal to $\mathrm{x}$ axis in shape of slender triangle, while part proximal to $\mathrm{x}$ axis shaped into broad rectangle. Indentation in lower central part is present and directed towards apophysis of ray in most denticles. Ray connection strongly developed, almost of same thickness as base of ray. Anterior ray apophysis present, delicate and directed anteriorly. Rays robust and basically same thickness for most of ray length. Rays taper slightly at tips producing narrower but rounder tips. Rays directed predominantly in posterior direc- tion, some touching or even crossing $\mathrm{y}-1$ axis. Ratio of denticle above and below $\mathrm{x}$ axis is $0.78(0.8-1.0)$.

Population B (Fig. 7b): Blade robust, almost Ushaped, filling most of area between y axes. Distal blade margin slightly rounded, mostly smooth, sloping gradually with larger posterior part of distal margin parallel to border membrane and smaller anterior margin at angle to border membrane. Tangent point relatively narrow, situated slightly proximal to distal blade margin. Anterior blade margin mostly smoothly rounded, extending slightly past y axes in all cases. Blade apophysis present and prominent. Posterior blade surface deep U-shape, with deepest point almost halfway to $\mathrm{y}+1$ axis, and deepest point slightly proximal to blade apex. No posterior projection present / observed. Blade connection broad but thinner than central part width. Central part robust with smooth proximal and distal edges, broad and squat, extending almost halfway to $y$ axes. Central part distal to $\mathrm{x}$ axis triangular with sloping edge, while part proximal to $\mathrm{x}$ axis shaped into broad shape, basically rectangular. No indentation in lower central part. Ray connection strongly developed, of same thickness as ray base. Anterior ray apophysis present, delicate and directed anteriorly. Rays robust and of same thickness for whole ray length, ending in strongly blunt rounded tips. Rays all directed prominently in posterior direction, all clearly crossing y axes. Ratio of denticle above and below $\mathrm{x}$ axis $0.81(0.78-0.86)$.

Population C (Fig. 7c): Blade robust and angular, open C-shaped, filling up large but not most part of area between y axes. Small part of posterior distal blade margin parallel to border margin, with largest part of distal blade margin sloping strongly away from border membrane. Tangent point narrow, situated proximal to distal blade margin. Anterior blade margin smooth but angular and narrow, extending well past y axes in all cases. Blade apophysis present and strongly developed, in most cases proximal edge of anterior blade margin with two prominent notches. Posterior blade surface L-shaped, with deepest point well proximal to blade apex. Posterior projection present and prominent, forming strong step-like notch into which following denticle fits with prominent corresponding notch distal to central part. Blade connection well developed, but thinner than central part width. Central part robust with smooth proximal and distal edges, fitting tightly into preceding denticle and extending more than halfway to y axes. Shape range from almost slender to broad with base as wide as rest of central part. Central part distal to $\mathrm{x}$ axis similar to proximal part. No indentation in 


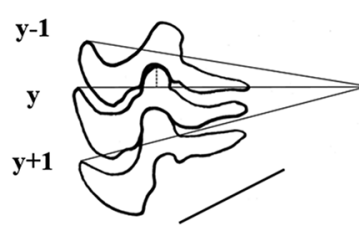

a

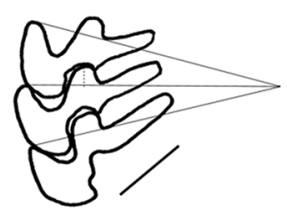

b

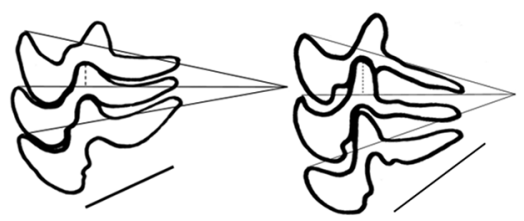

c

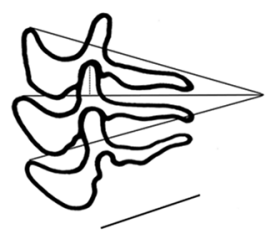

e

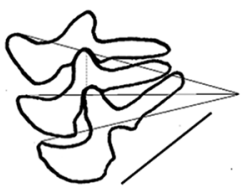

f

Figs 7a-f. Comparisons of denticles redrawn from micrographs taken of a - Trichodina heterodentata Duncan, 1977, Population A, b - T. heterodentata Duncan, 1977, Population B, c - T. heterodentata Duncan, 1977, Population C, d - T. hypsilepis Wellborn, 1967, e - T. salmincola Wellborn, 1967 and $\mathbf{f}-$ T. vallata Wellborn, 1967 paratypes housed at the Smithsonian Museum, USA.

lower central part. Ray connection strongly developed, but slightly narrower than base of ray. Ray apophysis present, delicate and directed anteriorly. Rays robust, prominently widening directly after ray connection and then gradually tapering to narrow, rounded tips. Rays lightly curved, though directed mostly towards centre of adhesive disc, some rays directed slightly in posterior direction, touching and barely crossing y-1 axis. Ratio of denticle above and below $\mathrm{x}$ axis 0.85 (0.79-0.92).

Remarks: The denticle structure of both populations $A$ and $B$ is very similar in all criteria, differing only marginally, for instance the absence of the indentation in the lower central part (population B), where it is present and directed towards the apophyses of the rays in population A. Another difference is that all the rays of population B clearly cross the y axis, whereas some rays touch while others cross the y axis in population A. These differences still fall well within the variation demonstrated by all other records for $T$. heterodentata. However, population $\mathrm{C}$ shows prominent characteristics in denticle shape that has not been reported from any other populations. The anterior blade margin is clearly angular and narrow, extending well past the y axis in all cases, the blade apophysis is strongly developed and in most cases the proximal edge of the anterior blade margin has two uniquely prominent notches never observed for this species. Furthermore, the deepest point of the posterior blade surface lies well proximal to the blade apex. Finally, another distinct feature is the prominent posterior projection forming strong step-like notches into which the following denticle fits with conspicuous corresponding notches distal to the central part (Fig. 7c).

Trichodina hypsilepis Wellborn, 1967 (Figs 4 and 7d) (Table 1)

Host: Notropis hypsilepis Suttkus and Raney, 1955, highscale shiner.
Location on host: Body and fins.

Locality: Halawakee Creek, Chambers County, Alabama and the Chattahoochee River, Chambers County, Alabama, USA.

Type-specimens: Holotype USNM Helm. Coll. No. 64651 and one paratype slide and USNM Helm. Coll. No. 61652 (Smithsonian).

Description: Remeasured type material results and Wellborn's (1967) original morphometric data are provided in Table 1.

Blade strongly developed, semi-circular, filling most of area between y axes. Distal blade margin smoothly rounded, not parallel to border membrane, but gradually angling proximally towards anterior margin. Tangent point narrow, situated almost at same level as distal blade margin. Anterior blade margin mostly smoothly rounded, extending to and sometimes slightly past $\mathrm{y}+1$ axis. Blade apophysis present and prominent. Posterior blade surface performs smooth semi-lunar curve, C-shaped, with deepest point at same level as blade apex. Clear notch in proximal blade margin anterior to apophysis. Posterior projection not visible. Blade connection narrow. Central part well developed, but slender and elongated, fitting tightly into preceding denticle and extending most of the way towards y axes. Central part distal to $\mathrm{x}$ axis in shape of elongated slender triangle, while part proximal to $\mathrm{x}$ axis slender, almost rectangular. Clear indentation in lower central part present, accommodating apophysis of preceding ray. Ray connection well developed to delicate, only slightly thinner than base of ray. Anterior ray apophysis present and prominent, directed anteriorly. Rays straight, strongly developed, but slender, of equal thickness for whole length of ray. Rays taper slightly to small rounded tips. Most rays directed straight towards centre of disc, with a few directed only slightly in anterior direction. Ratio of denticle above and below $\mathrm{x}$ axis is 0.7 . 
Trichodina salmincola Wellborn, 1967 (Figs 5 and 7e) (Table 2)

Host: Oncorhynchus mykiss (Walbaum, 1792), rainbow trout.

Location on host: Fins and body.

Locality: Haywood county, North Carolina.

Type-specimens: Holotype USNM Helm. Coll. No. 61657 and one paratype USNM Helm. Coll. No. 61658.

Description: Remeasured type material results and Wellborn's (1967) original morphometric data are provided in Table 2.

Blade strongly developed, semi-circular, filling most of area between y axes. Distal blade margin not parallel to border membrane, gradually sloping proximally towards anterior margin. Tangent point small, situated proximally to distal blade margin. Anterior blade margin smoothly rounded towards apex, with rounded apex not reaching $\mathrm{y}+1$ axis in some blades, but touching or extending slightly past y axes. Blade apophysis present and prominent. Posterior blade surface performs smooth shallow to L-shaped curve, with deepest point either at same level or somewhat proximal to blade apex. Posterior projection not visible. Clear notch in proximal blade margin anterior to apophysis. Blade connection narrow. Central part well developed, elongated, fitting tightly into preceding denticle, extending all the way and touching y-1 axis, curving slightly proximally. Central part distal to $\mathrm{x}$ axis slightly larger and in shape of elongated slender triangle, in contrast to part proximal to $\mathrm{x}$ axis shaped into very slender rectangle. Indentation in lower central part not visible. Ray connection delicate, slightly thinner than base of ray. Anterior ray apophysis present and prominent, directed distally in some and slightly anteriorly in others. Majority of rays straight, some minimally curved. Majority directed straight towards centre of disc with a few directed only slightly in anterior direction. Rays very slender and delicate, of equal thickness for whole length of ray, then tapering slightly to small bluntly rounded tips. Ratio of denticle above and below $\mathrm{x}$ axis is 0.79 (0.74 to 0.84$)$.

Trichodina vallata Wellborn, 1967 (Figs 6 and 7f) (Table 2)

Host: Ictalurus punctatus (Rafinesque, 1818), channel catfish.

Location on host: Fins, body and gills.

Locality: National Fish Hatchery, Whitfield County, Georgia.

Type-specimens: Holotype in USNM Helm. Coll. No. 61662 .
Description: Remeasured type material results and Wellborn's (1967) original morphometric data are provided in Table 2.

Blade strongly developed, sickle-shaped, filling most of area between y axes. Distal blade margin not parallel to border membrane, gradually sloping proximally towards anterior margin. Tangent point small, situated proximally to distal blade margin. Anterior blade margin rounded towards apex, with rounded apex not reaching $\mathrm{y}+1$ axis in some blades, but touching or extending slightly past y axes in others. Blade apophysis present and prominent. Posterior blade surface performs smooth shallow curve, slight C- to L-shaped, with deepest point at same level of blade apex. Clear notch in proximal blade margin anterior to apophysis. Posterior projection not clearly visible. Blade connection broad. Central part well developed, robust and squat, fitting tightly into preceding denticle and extending all the way to and even touching y axes. Central part distal to $\mathrm{x}$ axis slightly smaller and in shape of elongated slender triangle, in contrast to part proximal to $\mathrm{x}$ axis shaped into very slender rectangle. Distal edge slopes gradually in anterior direction, while proximal edge of central part has edge straighter in anterior direction. Indentation in lower central part small and inconspicuous. Ray connection strong, only slightly thinner than base of ray. Anterior ray apophysis present and prominent, directed in anterior-distal direction. Rays robust, becoming slightly thicker directly after connection, tapering towards bluntly rounded tips. Rays vary from directed sharply anteriorly to sharply posteriorly, crossing y axes in both directions. Ratio of denticle above and below $\mathrm{x}$ axis is 0.80 ( 0.79 to 0.82$)$.

\section{Trichodina funduli Wellborn, 1967 (Table 2)}

Host: Fundulus notti (Agassiz, 1854), starhead topminnow.

Location on host: Body and fins

Locality: Swift Creek, Autauga County, Alabama.

Type-specimens: Holotype USNM Helm. Coll. No. 61645 and paratype USNM Helm. Coll. No. 61646.

Description: Remeasured type material results and Wellborn's (1967) original morphometric data are provided in Table 2.

The silver nitrate impregnation of Wellborn's (1967) original holotype and paratype material was of such quality that denticle structures could not successfully be drawn for descriptive purposes.

Remarks: The denticle structures of T. hypsilepis, T. salmincola and T. vallata exhibit remarkably similar 


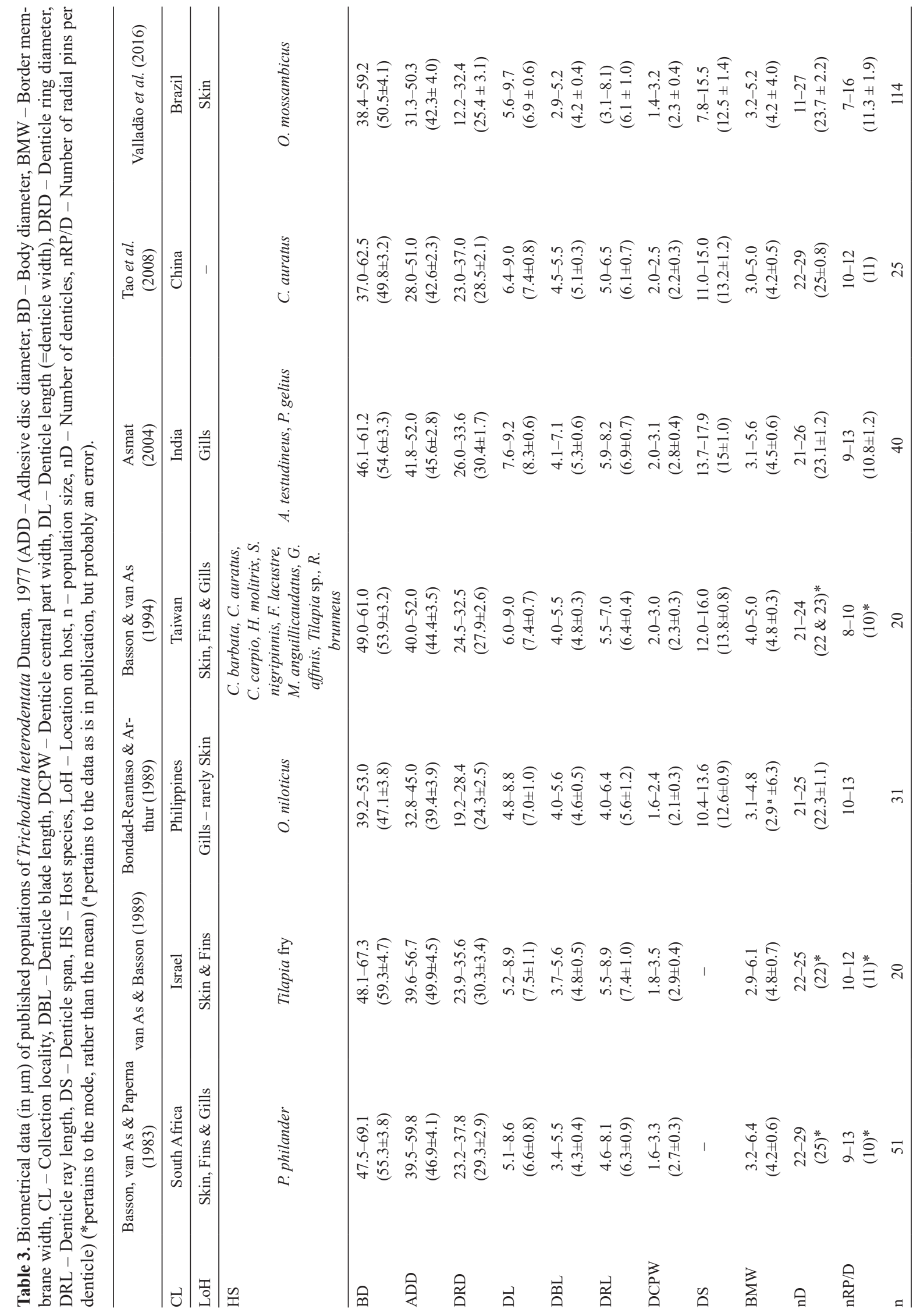




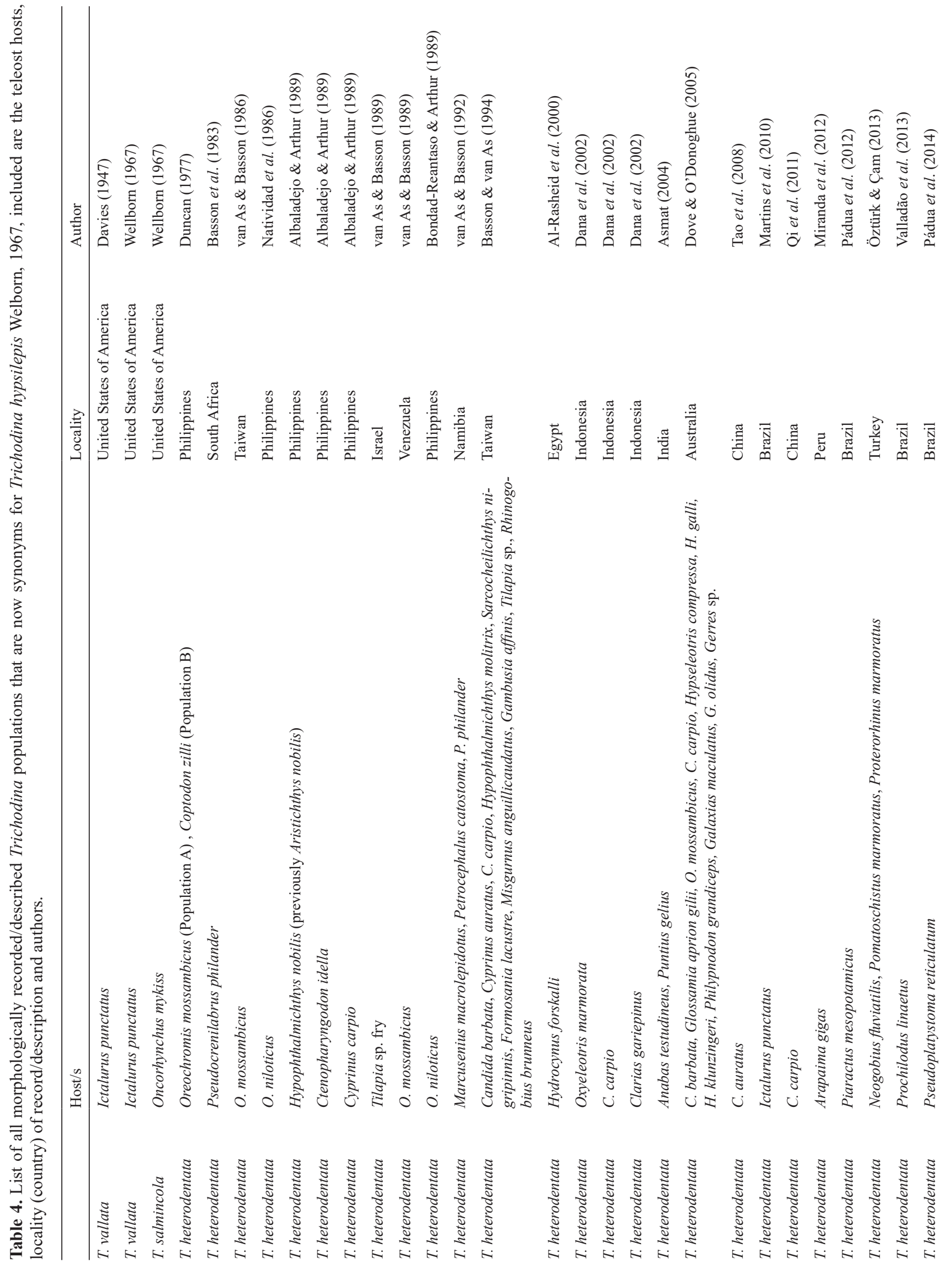




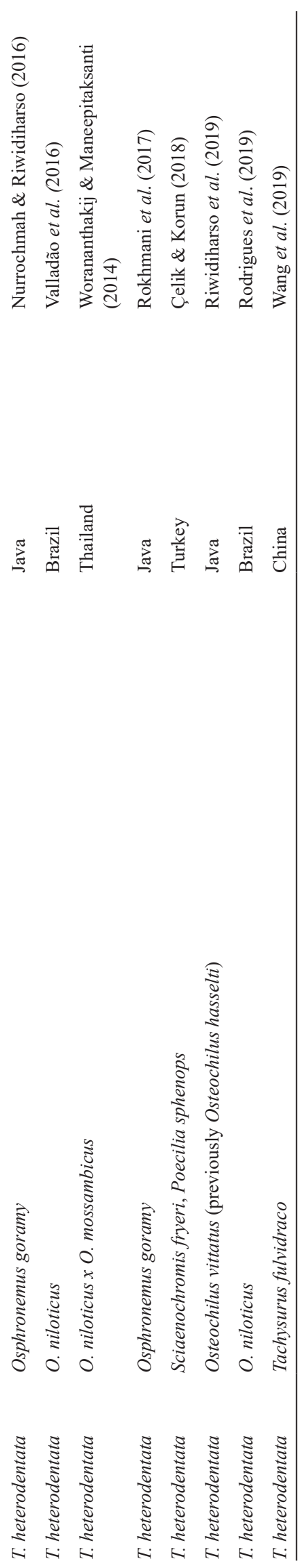

traits with minor differences. For both $T$. hypsilepis and T. salmincola the blade connections are narrow, but broad for $T$. vallata. The central part extends most of the way towards the y axis for T. hypsilepis, whereas in the case of both $T$. salmincola and $T$. vallata the central part extends all the way to and touches the y axis. The ray connection is strongly developed for T. hypsilepis and $T$. vallata, but delicate in T. salmincola. The rays differ for all three species where the rays are strongly developed, but slender (T. hypsilepis), very slender and delicate (T. salmincola) and robust becoming slightly thicker towards the ray connection (T. vallata).

\section{DISCUSSION}

Trichodina heterodentata characteristically shows a range of variation in both denticle morphology and morphometrics worldwide (Tables 1 and 3). The body diameter of this species is just such an example; there is variation across, and even within populations of $T$. heterodentata described from a large number of teleost species. However, in some cases this large variation in body diameter can be misleading, mainly due to the measuring differences between the two historic schools of trichodinid research, where most of the earlier authors used Dogiel's 1940 method of measuring the span of the whole soft body for body diameter (Lom 1958), compared to the current accepted method by most workers of measuring the adhesive disc plus the border membrane (Basson et al. 1983). Duncan (1977) and many other authors, did not state exactly how the body diameter was measured, therefore it was decided to disregard this measurement, but rather use the adhesive disc diameter for comparative size groupings of the populations under discussion. Adhesive disc diameter variation makes it possible to clump this species into three overarching groups. Group I, observed from teleost hosts from Thailand (Worananthakij and Maneepitaksanti 2014), Taiwan (Basson and van As 1994) and the Philippines (Duncan 1977) comprises the "largest" described populations with a mean adhesive disc diameter larger than $61 \mu \mathrm{m}$. Members of group II ("middle sized"), are between 51 and $60 \mu \mathrm{m}$ recorded exclusively from teleost hosts from Indonesia (Albaladejo and Arthur 1989, Dana et al. 2002, Nurrochmah and Riwidiharso 2016), Australia (Dove and O'Donoghue 2005) and Venezuela (Basson and van As 1989). Group III ("smallest") includes those populations with a mean 
diameter of between 35 and $50 \mu \mathrm{m}$ from South America (Martins et al. 2010; Pádua et al. 2012; Miranda et al. 2012; Valladão et al. 2013, 2016), Africa (Basson et al. 1983, van As and Basson 1992, Al-Rasheid et al. 2000), the Middle East (van As and Basson 1989, Öztürk and Çam 2013), the Far East (Albaladejo and Arthur 1989, Basson and van As 1994, Asmat 2004, Tao et al. 2008) and the Philippines (Bondad-Reantoso and Arthur 1989). This last group boasts with the majority of records and includes all reported populations from amphibian tadpole hosts (Kruger et al. 1993, Dias et al. 2009, Pala et al. 2018).

Re-examining Duncan's (1977) material, it is clear that two of his populations; A and B (both from cichlid hosts) have the typical and recognised $T$. heterodentata morphometrics (Table 1, Figs 1 and 2 respectively), but with a larger body diameter than any other recorded in the literature (Table 3). His third population, C (Fig. 3 ) deviates from the previously mentioned populations and all other published records of $T$. heterodentata (Table 3 ) as this population: (i) is extremely homogeneous, which is not an attribute of this species, (ii) the denticle and body measurements fall into the top range of Group I, while most of the measured population consists of immature individuals and (iii) the denticle morphology is atypical for T. heterodentata, as per the denticle description method of van As and Basson (1989). We suspect that this species is not $T$. heterodentata, but will refrain from elaborating on this in the present paper.

Amongst the mobiline species described by Wellborn (1967), four of these (T. hypsilepis, T. salmincola, T. vallata and $T$. funduli) appeared to be remarkably similar in denticle shape, form and size. For this reason, photomicrographs from the original type material was acquired from the Smithsonian Museum (Washington, D.C.) and re-examined by using both Lom's (1958) and the van As and Basson (1989) denticle description methods. Due to de-staining of the silver nitrate impregnation over time, no feasible material could be measured for T. funduli, making acceptable taxonomic inferences about this species impossible.

After comparing the denticle morphology and morphometrics of $T$. hypsilepis, $T$. salmincola, $T$. vallata and $T$. heterodentata we conclude that these all belong to the same taxon. The International code of Zoological nomenclature (Ride et al. 1985) states in Article 23, that the Principle of Priorities (using the oldest available name for a valid taxon) must always be applied. This implies that the lesser known T. hypsilepis be the valid taxon with $T$. salmincola, $T$. vallata along with the cosmopolitan and widely studied $T$. heterodentata from all teleost hosts as synonyms.

The species originally described as $T$. heterodentata showed a clear preference for cichlid hosts, with strong evidence that this trichodinid originates from Africa. If this assumption is correct, the next question to be asked is how, and through what mechanism an African trichodinid got into the North American river systems? The translocation of $O$. mossambicus (endemic to the eastern part of southern African) due to aquaculture ventures worldwide is significant.

Oreochromis mossambicus was initially exported from Africa to the East. The first stock, according to Guerrero (1994) was brought to Java by East African traders in 1938, from there they were exported into most of Pacific Asia and eventually to the Philippines, through Thailand during the 1950s and 60s (De Silva et al. 2004). At the same time 60 Mozambique tilapias were sent from Singapore to Hawaii in 1954, and the progeny of these fish were then sent to the public aquarium in New York, where in turn, the offspring of those were sent to Alabama (Rogers 1961, Smith-Vaniz 1968), Arizona (Hoover and St. Amant 1970, Minckley 1973) and California (St. Amant 1966) for aquaculture purposes or sport fishing. At this time many tilapias escaped into the natural water systems during loading and harvesting or through containment failures, resulting in the first reported Mozambique tilapia in the Alabaman River System in 1965, which is the same river system in which T. hypsilepis, was first described in 1967. This distribution and introduction of $O$. mossambicus across the East into the southern states of North America supports the present theory that T. hypsilepis and T. heterodentata indeed represent the same species.

To confuse matters more, Kazubski (1986) described a species, T. equatorialis Kazubski, 1986, based on a population from unidentified cichlids from Kenya. With this publication Kazubski (1986) suggested that T. hypsilepis (syn. T. heterodentata) described from South Africa and Israel by Basson et al. (1983) be designated as a synonym of $T$. equatorialis and furthermore that T. hypsilepis does not occur in Africa. This species cannot be equated to T. hypsilepis, as it was quite large (with body diameter of 72 to $84 \mu \mathrm{m}$ and adhesive disc diameter 45-52 $\mu \mathrm{m}$ ), much larger that any other T. hypsilepis recorded from Africa and Israel and that the denticle shape provided by the diagrammatic illustration does not resemble any $T$. hypsilepis population worldwide. These large dimensions and characteristic denticle shape most probably resembles another cichlid 
trichodinid from Africa; T. magna van As and Basson, 1983 (van As and Basson 1989). Due to the absence of any silver impregnated micrographs as per Lom (1958), the validity of this taxon and its relationship to T. mag$m a$ can unfortunately not be validated. However, this species shows no relationship to T. hypsilepis, and nullifies Kazubski's (1986) claim that T. hypsilepis (syn. T. heterodentata) from Africa and Israel is a synonym of T. equatorialis, as also concluded by Bondad-Reantaso and Arthur (1989).

The trichodinid taxon known up to now as $T$. heterodentata has not only been described from fish hosts, but also from anuran tadpoles, although all amphibian host observations have been restricted to the Southern Hemisphere. The anuran trichodinids seem to paint a completely different picture; which will be addressed in de Jager et al. (2019) focussing on morphometric and molecular results.

To avoid more confusion in the already bewildering world of mobiline taxonomy, Table 4 is included with all the recorded valid populations that will henceforth be known as synonyms of Trichodina hypsilepis Wellborn, 1967. There are several reports of T. heterodentata from various countries which have not been included in Table 4, due to the fact that either no taxonomic description (just a record) or quality micrographs were included (Pádua et al. 2014; Dar et al. 2016; Tanry et al. 2016; Utami and Rokhmani 2016; Santos et al. 2017; Rokhmani et al. 2018, 2019; Enyidi and Uwanna 2019; Maneepitaksanti et al. 2019).

This case study illustrates that the weight of almost 200 years of diligent morphological techniques cannot be ignored, especially when it comes to investigating historical data and making taxonomic inferences from it. It also illustrates that morphology cannot stand alone as the pinnacle of taxonomy, because without the understanding of parasite-host interactions and knowledge of host distribution history those inferences would be mere sweeping statements.

Acknowledgements: The authors would especially like to thank Dr Anna J. Phillips, curator of clitellate and parasitic worms, Department of Invertebrate Zoology, Smithsonian Institute, Museum of Natural History for providing permission and assisting with taking the micrographs of the original Wellborn (1967) and Duncan (1977) slides at the Smithsonian Parasitology Collection, Washington, D.C. and Ms. Freya Goetz, Museum Technician; Illustration and Imaging, Department of Invertebrate Zoology, Smithsonian Institute, Museum of Natural History for skilfully taking the micrographs.

We would like to acknowledge the contribution and support of our mentor, colleague and friend, the late Prof. Jo van As.
Compliance with ethical standards - Ethical clearance obtained (UFS-AED2017/17), no fresh material collected.

Conflict of interest - The authors declare that they have no conflict of interest.

\section{REFERENCES}

Al-Rasheid K. A. S., Ali M. A., Sakran T., Abdel Baki A. A., Abdel Ghaffar, F. A. (2000) Trichodinid ectoparasites (Ciliophora: Peritrichida) of some River Nile fish, Egypt. Parasitol. Int. 49: 131-137

Albaladejo J. D., Arthur J. R. (1989) Some trichodinids (Protozoa: Ciliophora: Peritrichida) from freshwater fishes imported into the Philippines. Asian Fish. Sci. 3:1-25

Asmat G. (2004) First record of Trichodina diaptomi (Dogiel, 1940) Basson and Van As, 1991, T. heterodentata Duncan, 1977 and T. oligocotti (Lom, 1970) (Ciliophora: Trichodinidae) from Indian fishes. Pak. J. Biol. Sci. 7: 2066-2071

Basson L., van As J. G. (1989) Differential diagnosis of the genera in the family Trichodinidae (Ciliophora: Peritrichida) with the description of a new genus ectoparasitic on freshwater fish from southern Africa. Syst. Parasitol. 13: 153-160

Basson L., van As J. G. (1991) Trichodinids (Ciliophora: Peritrichia) from a calanoid copepod and catfish from South Africa with notes on host specificity. Syst. Parasitol. 18: 147-158

Basson L., van As J. G. (1992) A redescription of Trichodina oxystelis Sandon, 1965 (Ciliophora: Peritrichida), a parasite of the marine prosobranch Oxystele from southern Africa. Syst. Parasitol. 22: 231-237

Basson L., van As J. G. (1994) Trichodinid ectoparasites (Ciliophora: Peritrichida) of wild and cultured freshwater fishes in Taiwan, with notes on their origin. Syst. Parasitol. 28: 197-222

Basson L., van As J. G. (2006) Trichodinidae and other ciliophorans (Phylum Ciliophora). In: Fish diseases and disorders. Volume 1: Protozoan and Metazoan Infections, (Ed. P.T.K. Woo). CAB International, Oxfordshire, 154-182

Basson L., van As J. G., Paperna I. (1983) Trichodinid ectoparasites of cichlid and cyprinid fishes in South Africa and Israel. Syst. Parasitol. 5: 245-257

Bondad-Reantoso M. G., Arthur J. R. (1989) Trichodinids (Protozoa: Ciliophora: Peritrichida) of Nile Tilapia (Oreochromis niloticus) in the Philippines. Asian Fish. Sci. 3: 27-44

Carnaccini S., Lowenstine L. J., Sentíes-Cué C. G., Nyaoke A., Bland M., Bickford A. A. Shivaprasad H. L., Stoute S. T. (2016) Trichodinosis associated with pathology of the reproductive tract in waterfowl. Avian Pathol. 45: 418-425

Çelik S. Y., Korun J. (2018) Türkiye'den trichodinid protozooan Trichodina heterodentata ve T. pediculus (Ciliophora: Trichodinidae) için yeni konak kayd1. Kocatepe Vet. J. 11: 245-254

Dana D., Hadiroseyani K. S. Y. (2002) Trichodinid (Ciliophora: Peritrichida) ectoparasites of Sand Goby (Oxyeleotris marmorata) fry. JAI 1: 5-8

Davies H. S. (1947) Studies of the protozoan parasites of freshwater fishes. Fish. Bull. 41: 1-29

de Silva S. S., Subasinghe R. P., Bartley D. M., Lowther A. (2004) Tilapias as alien aquatics in Asia and the Pacific: a review. FAO Fisheries Technical Paper. No. 453. FAO, Rome, 65

Dar S. A., Kaur H., Chishti M. Z., Ahmad F., Dar G. H. (2016) First record of protozoan parasites in cyprinid fish, Schizothorax niger Heckel, 1838 from Dal lake in Kashmir Himalayas with study on their pathogenesis. Microbial. Pathogenesis 93: 100-104 
de Jager G. P., Basson L., van Marwijk J. (2019) A new Trichodina species (Peritrichia: Mobilida) from anuran tadpole hosts, Sclerophrys spp. in the Okavango Panhandle, Botswana, with comments on this taxon. Acta Protozool. 58: 141-153

Dias R. J. P., Fernandes N. M., Sartini B., da Silva-Neto I. D., D'Agosto M. (2009) Occurrence of Trichodina heterodentata (Ciliophora: Trichodinidae) infesting tadpoles of Rhinella pombali (Anura: Bufonidae) in the Neotropical area. Parasitol. Int. 58: $471-474$

Dogiel V. A. (1940) On the classification of the genus Trichodina. Trudy Leningradsk. 68: 8-31

Dove A. D. M., O’Donoghue P. J. (2005) Trichodinids (Ciliophora: Trichodinidae) from native and exotic Australian freshwater fishes. Acta Protozool. 44: 51-60

Duncan B. L. (1977) Urceolariid ciliates, including three new species, from cultured Philippine fishes. Trans. Am. Microsc. Soc. 96: $79-81$

Enyidi U., Uwanna P. (2019) Parasites of African Catfish Clarias gariepinus and Oreochromis niloticus Polycultured in Earthen Ponds. Aquast. 19: 81-89

Fulton J. F. (1923) Trichodina pediculus and a new closely related species. Proc. Boston Soc. Nat. Hist. 37: 1-29

Guerrero R. (1994) „Tilapia Farming in The Philippines - A Success Story." APAARI Publication no. 1994/2. APAARI, Bangkok

Hirschfield H. (1949) The morphology of Urceolaria karyolobia, sp. nov., Trichodina tegula, sp. nov., and Scyphidia ubiquita, sp. nov., three new ciliates from southern California limpets and turbans. J. Morphol. 85: 1-29

Hoover F. G., St. Amant J. A. (1970) Establishment of Tilapia mossambica (Peters) in Bard Valley, Imperial County, California. Calif. Fish Game 56: 70-71

$\mathrm{Hu}$ Y. (2011) Description of a new genus Heterobladetrichodina, n.g. (Ciliata: Trichodinidae) with a new species from Ictalurus punctatus in China. Eur. J. Sci. Res. 60: 316-323

Kazubski S. L. (1986) The trichodinid ciliates from fish, Tilapia sp. from Lake Victoria (Kenya) and description of Trichodina equatorialis nom. nov. Acta Protozool. 25: 445-448

Kazubski S. L. (1988) Morphological variation in a ciliate, Trichodina reticulata Hirschman \& Partsch, 1955 (Peritrichida), in tadpoles from small ponds. Acta Protozool. 27: 259-269

Kazubski S. L. (1991) Morphological variation of the ciliate Trichodina pediculus Ehrenberg 1838: I. parasitizing on hydras. Acta Protozool. 30: 169-175

Klein B. M. (1926) Die Silberliniensysteme der Ciliaten. ihr Verhaken wahrend Teilung und Conjugation. Arch. Protistenkd. 58: 55-142

Kruger J., Basson L., van As J. G. (1991) Redescription of Trichodina xenopodos Fantham, 1924 (Ciliophora: Peritrichida), a urinary bladder parasite of Xenopus laevis laevis (Daudin, 1802), with notes on transmission. Syst. Parasitol. 19: 43-50

Kruger J., van As J. G., Basson L. (1993) Trichodina heterodentata Duncan, 1977 (Ciliophora: Peritrichida), an ectoparasite on larvae of the African Clawed Toad Xenopus laevis laevis (Daudin, 1802). Acta Protozool. 32: 255-259

Kruger J., van As J. G., Basson L. (1995) Observations on the adhesive disc of Trichodina xenopodos, Fantham, 1924 and T. heterodentata Duncan, 1977 (Ciliophora: Peritrichida) during binary fission. Acta Protozool. 34: 203-209

Lom J. (1958) A contribution to the systematics and morphology of endoparasitic trichodinids from amphibians, with a proposal of uniform specific characteristics. J. Protozool. 5: 251-263

Maneepitaksanti W., Tapingkale W., Moonmanee T., Gatphayak K. (2019) Histopathology of Mekong Giant Catfish (Pangasian- odon gigas) infected with columnaris bacteria in Chiang Mai province, Thailand. Microsc. Microanal. Res. 32: 23-25

Martins M. L., Marchiori N., Nunes G., Rodrigues M. P. (2010) First record of Trichodina heterodentata (Ciliophora: Trichodinidae) from channel catfish, Ictalurus punctatus cultivated in Brazil. Brazil. J. Biol. 70: 637-644

Minckley W. L. (1973) Fishes of Arizona. Arizona Fish and Game Dept. Sims Printing Company Inc., Phoenix, 293

Miranda L. H., Marchiori N., Alfaro C. R., Martins M. L. (2012) First record of Trichodina heterodentata (Ciliophora: Trichodinidae) from Arapaima gigas cultivated in Peru. Acta Amaz. 42: 433-438

Mueller J. F. (1937) Some species of Trichodina (Ciliata) from freshwater fishes. Trans. Am. Microsc. Soc. 56: 177-184.

Natividad J. M., Reantaso M. G. B., Arthur J. R. (1986) Parasites of Nile tilapia (Oreochromis niloticus) in the Philippines. In: The First Asian Fisheries Forum in the Philippines, (Eds. J. L. Maclean, L. B. Dizon, L. V. Hosillos). Asian Fish Society, Manilla, 255-259

Nurrochmah H. S., Riwidiharso E. (2016) Kelimpahan dan variasi morfometrik Trichodina sp. pada benih ikan Gurami (Osphronemus gouramy Lac.) di kolam budidaya Desa Baji Kecamatan Kedungbanteng Banyumas. In: Seminar Nasional Pendidikan dan Saintek: 473-480

Öztürk T., Çam A. (2013) Trichodinid parasites (Protozoa: Ciliophora: Peritrichida) of invasive gobiid fish inhabiting the lower Kizilırmak delta in Samsun, Turkey. Pak. J. Zool. 45: $1517-1524$

Pádua S. B., Martins M. L., Carraschi S. P., Cruz C., Ishikawa M. (2012) Trichodina heterodentata (Ciliophora: Trichodinidae): a new parasite for Piaractus mesopotamicus (Pisces: Characidae). Zootaxa 3422: 62-68

Pádua S. B., Jerônimo G. T., Ishikawa M. M., Belo M. D. A., Martins M. L., Pelisari T., Kasai R. Y. D., Carrijo-Mauad, J. R. (2014) Parasitological assessment and host-parasite relationship in farmed Cachara catfish fingerlings (Pseudoplatystoma reticulatum Eigenmann \& Eigenmann 1889), Mato Grosso do Sul, Brazil. Neotrop. Helminthol. 8: 37-45

Pala G., Valladão G. M. R., Alves L. O., Pilarski F., Hopp E. L. (2018) Tadpoles of Rhinella schneideri as reservoirs of trichodinids in continental aquaculture. Aquaculture 488: 17-21

Qi H., Zhao Y., Tang F. (2011) Studies on ectoparasitic trichodinids from Cyprinus carpio in the upper reaches of the Yangtze River, Sichuan Branch. J. Chongqing Norm. Univ. Nat. Sci. Ed. 28:16-24

Ride W. D. L., Sabrosky C. W., Bernardi G., Melville R. V. (Eds.) (1985) International code of zoological nomenclature adopted by the XX General Assembly of the International Union of Biological Sciences Third Edit., London: International Trust for Zoological Nomenclature

Riwidiharso E., Alfarisi B., Rokhmani R. (2019) Morfologi dan intensitas Trichodina spp. pada benih ikan nilem (Osteochilus hasselti) milik Balai Benih Ikan Kutasari Purbalingga, Jawa Tengah. Pros. Sem. Nas. Masy. Biodiv. Indon. 5: 316-323

Rodrigues F. S., Assane I. M., Valladão G. M. R., Paula F. G. D., Andrade C. L., Moraes A. P. D., Dall'Agnol M., Pascoal L. M. (2019) First report of Trichodinella and new geographical records of trichodinids in Nile tilapia (Oreochromis niloticus) farmed in Brazil. Rev. Bras. Parasitol. Vet. 28: 229-237

Rogers W. A. (1961) Second progress report on stocking and harvesting of tilapia and channel catfish in Alabama's state-owned and managed public fishing lakes. Federal Aid Project F-10, Alabama Department of Conservation, Alabama, 10 
Rokhmani R., Ariyani E., Joko D. W. (2017) Hubungan kekerabatan genetik Trichodina sp. dan patogenisitasnya yang menginfeksi benih gurame sebagai upaya pengendaliannya dini di kabupaten Exs. karesidenan banyumas jawa tengah. Prosiding. 7

Rokhmani R., Setyawati E. A.,Wahyono, D. J. (2018) Moleculer detection of protozoa Trichodina spp. in gourami (Osphromenus gourame Lac.) larvae with the infecting 18S rRNA gene marking in Exs. residence of Banyumas, Central Java. IUFS J. Biol. 10: $320-325$

Rokhmani R., Riwidiharso E., Darsono D., Utami P. (2019) Variasi morfologi, prevalensi dan intensitas Trichodina spp. pada ikan hasil tangkapan di Sungai Kranji Purwokerto, Jawa Tengah. Pros. Sem. Nas. Masy. Biodiv. Indon. 5: 312-315

Santos M. A., Jerônimo G. T., Cardoso L., Tancredo K. R., Medeiros P. B., Ferrarezi J. V., Gonçalves E. L. T., da Costa Assis G., Martins M. L. (2017) Parasitic fauna and histopathology of farmed freshwater ornamental fish in Brazil. Aquaculture 470: 103-109

Smith-Vaniz W. F. (1968) Freshwater Fishes of Alabama. Auburn University Agricultural Experiment Station, Auburn, Alabama, 211

St. Amant J. A. (1966) Addition of Tilapia mossambica Peters to the California fauna. Calif. Fish Game 52: 54-55

Tao F. H., Zhao Y. J., Tang F. H. (2008) Seven species of trichodinid ectoparasites (Ciliophora: Peritrichida) from freshwater fishes, Hypophthalmichthys molitrix, Aristichthys nobilis and Ctenopharyngodon idellus, with the description of Trichodina chongqingensis sp. nov. Acta Hydrobiol. Sin. 32: 124-129

Tanry T. A., Nazir R., Chishti M. Z., Ahmad F., Dar G. H., Dar, J. S. (2016) A report on the incidence of Trichodina heterodentata from fishes of Jammu, J\&K India. JOPD 40: 524-527

Utami P., Rokhmani D. E. R. (2016) Spesifisitas parasit protozoa Trichodina sp. pada gurame, tawes, Nilem dan Nila yang Dibudidayakan polikultur. In: Seminar Nasional Pendidikan dan Saintek: 86-91

Uzmann J. R., Stickney A. P. (1954) Trichodina myicola n. sp., a peritrichous ciliate from the marine bivalve Mya arenaria (L.). J. Protozool. 1: 149-155

Valladão G. M. R., Gallani S. U., de Pádua S. B., Martins M. L., Pilarski F. (2013) Trichodina heterodentata (Ciliophora) infesta- tion on Prochilodus linaetus larvae: A host-parasite relationship study. Parasitology 141: 662-669

Valladão G. M. R., Alves L., Pilarski F. (2016) Trichodiniasis in Nile tilapia hatcheries: Diagnosis, parasite: host-stage relationship and treatment. Aquaculture 451: 444-450

van As J. G., Basson L. (1986) Trichodinids (Ciliophora: Peritricha) ectoparasites of cultured cichlids from Taiwan. Bull. Inst. Zool. Acad. Sin. 25: 135-139

van As J. G., Basson L. (1989) A further contribution to the taxonomy of the Trichodinidae (Ciliophora: Peritrichia) and a review of the taxonomic status of some fish ectoparasitic trichodinids. Syst. Parasitol. 14: 157-179

van As J. G., Basson L. (1992) Trichodinid ectoparasites (Ciliophora: Peritrichida) of freshwater fishes of the Zambesi River System, with a reappraisal of host specificity. Systematic Parasitology 22: 81-109

van As J. G., Basson L. (1993) On the biology of Pallitrichodina rogenae gen. n., sp. n. and P. stephani sp. n. (Ciliophora, Peritrichida), mantle cavity symbionts of the Giant African Snail Achatina in Mauritius and Taiwan. Acta Protozool. 32: 47-62

van As J. G., Basson L. (1996) An endosymbiotic trichodinid, Trichodina rhinobatae sp. n. (Ciliophora: Peritrichia) found in the Lesser Guitarfish, Rhinobatos annulatus Smith, 1841 (Rajiformes: Rhinobatidae) from the South African Coast. Acta Protozool. 35: 61-67

Wang Z., Zhou T., Yang H., Gu Z. (2019) First diagnosis of ectoparasitic ciliates (Trichodina and Chilodonella) on farmed juvenile yellow catfish, Tachysurus fulvidraco in China. Aquac. Res. 50: 3275-3285

Wilson J. R., Saunders R. J., Hutson K. S. (2019) Parasites of the invasive tilapia Oreochromis mossambicus: evidence for cointroduction. Aquat. Invasions, 14: 332-349.

Worananthakij W., Maneepitaksanti W. (2014) Identification of trichodinids (Ciliophora: Trichodinidae) from red tilapia (Oreochromis niloticus x O. mossambicus) in Pathumthani Province, Thailand. Kasetsart J. (Nat. Sci.) 12: 49-55

Wellborn T. L. (1967) Trichodina (Ciliata: Urceolariidae) of freshwater fishes of the South-eastern United States. J. Protozool. 14: $399-412$

Received on $1^{\text {st }}$ August, 2019; revised on 2019; accepted on 2019 